\title{
Filling the blank spot: first report on the freshwater crayfish distribution in Albania
}

\author{
Agata Mrugała ${ }^{1}$, Radek Šanda ${ }^{1}$, Spase Shumka ${ }^{2}$ and Jasna Vukić ${ }^{3, *}$ \\ ${ }^{1}$ Department of Zoology, National Museum, Václavské nám. 68, Prague 1 11579, Czech Republic \\ ${ }^{2}$ Faculty of Biotechnology and Food, Agricultural University of Tirana, Kodër Kamëz SH1, Tirana 1001, Albania \\ ${ }^{3}$ Department of Ecology, Faculty of Science, Charles University, Viničná 7, Prague 2 12844, Czech Republic
}

\begin{abstract}
The knowledge on the distribution of native and non-native crayfish species in Europe has substantially advanced during last two decades. However, data on the exact distribution of European crayfish are still lacking in some regions of the Balkan Peninsula, e.g., in Albania. Out of five European crayfish taxa, Astacus astacus and Austropotamobius torrentium are considered to occur in Albanian freshwaters. However, until now the only confirmed localities of the occurrence of any crayfish species in Albania are a single place in the Mat River drainage and Prespa Lake. Five crayfish individuals have been collected recently from two localities in Albania: Ohrid Lake and upper Devolli River (Seman basin), as a result of a repeated sampling in all main Albanian river drainages. All specimens were morphologically and molecularly identified as the noble crayfish, $A$. astacus, providing confirmation of its presence in this Balkan country. The present paper summarizes historic and current distribution records of the crayfishes in Albania and neighbouring countries as well as provides insight into genetic variability of Albanian A. astacus.
\end{abstract}

Keywords: Astacus astacus / Austropotamobius torrentium / Ohrid Lake / DNA barcoding / Balkan Peninsula

Résumé - Combler une lacune : premières données sur la distribution des écrevisses en Albanie. Les connaissances sur la répartition des espèces d'écrevisses natives et non autochtones en Europe ont considérablement progressé au cours des deux dernières décennies. Cependant, des données sur la répartition exacte des écrevisses européennes manquent encore dans certaines régions de la péninsule balkanique, par exemple en Albanie. Parmi les cinq taxa européens d'écrevisse, Astacus astacus et Austropotamobius torrentium sont considérés comme présentes dans les eaux albanaises. Cependant, jusqu'à présent, les seules localités confirmées de présence d'espèces d'écrevisses en Albanie sont un endroit unique dans le bassin de la rivière Mat et dans le lac Prespa. Cinq spécimens d'écrevisses ont été collectés récemment dans deux localités en Albanie : le lac d'Ohrid et la Haute-Devolli (bassin du Seman), à la suite d'un échantillonnage répété dans tous les principaux bassins hydrographiques albanais. Tous les spécimens ont été identifiés morphologiquement et génétiquement comme étant l'écrevisse noble, A. astacus, confirmant sa présence dans ce pays balkanique. Le présent document résume les rapports de distribution historiques et actuels des écrevisses en Albanie et dans les pays voisins, ainsi que des informations sur la variabilité génétique d'A. astacus albanais.

Mots-clés : Astacus astacus / Austropotamobius torrentium / Lac Ohrid / code barres ADN / Péninsule des Balkans

The European continent is inhabited only by five crayfish taxa from two genera: Astacus and Austropotamobius (as in Kouba et al., 2014). These include: the noble crayfish Astacus astacus, the thick-clawed crayfish Astacus pachypus, the narrow-clawed crayfish Astacus leptodactylus as well as the white-clawed crayfish Austropotamobius pallipes and the stone crayfish Austropotamobius torrentium (Kouba et al., 2014); with

\footnotetext{
${ }^{*}$ Corresponding author: jvukic@seznam.cz
}

the three latter taxa considered to possibly form species complexes (e.g., Grandjean et al., 2002; Klobučar et al., 2013; Maguire et al., 2014; Jelić et al., 2016). Similarly to other parts of the world, the European crayfish fauna has been subjected to considerable population declines (Richman et al., 2015), caused mainly by habitat degradation, as well as introduction of more competitive North American crayfish species and the crayfish plague pathogen, Aphanomyces astaci carried by them (Holdich et al., 2009). The extent of these losses is especially worrying as 
freshwater crayfish are important keystone species with a substantial effect on the function and structure of whole ecosystems (Reynolds et al., 2013).

The Balkan Peninsula is characterized by a high genetic diversity for many aquatic species (Bănărescu, 2004; Sket et al., 2004), stemming from its role as one of the most important Pleistocene glacial refugia in Europe (Hewitt, 1999). Likewise, the populations of some European crayfish species occurring in the Balkans were observed to exhibit higher genetic variation compared with the rest of Europe (Trontelj et al., 2005; Klobučar et al., 2013; Schrimpf et al., 2014), and hence forming genetically unique stocks of conservation importance on the continental scale. However, in contrast to most European countries, the detailed information on exact distribution of crayfish species in the Balkans is still scarce (Kouba et al., 2014) and has only been recently updated for some regions: Bosnia and Herzegovina, Croatia, Serbia and Montenegro (Simić et al., 2008; Maguire et al., 2011; TrožićBorovac, 2011). However, although out of four European crayfish species present in the Balkan Peninsula, two were considered to occur in Albania: A. astacus and A. torrentium, to the best of our knowledge no studies on their distribution have been published (e.g., Holdich, 2002). The assumption about their presence in this country has been mainly based on the records from the transboundary waterbodies outside Albania (Karaman, 1929, 1962, 1963; Albrecht, 1982; Subchev, 2011). The aim of the present paper is to summarize historic and current distribution records and our own investigations of European crayfish occurrence in Albania, and contribute to the understanding of crayfish distribution on the Balkan Peninsula.

From 2004 to 2015, during several ichthyological surveys covering comprehensively the watercourses of all main Albanian rivers, we searched also for the presence of crayfish species. Crayfish were found only in 2015 at two locations: upper Devolli River in Seman basin (4 individuals; N 40 42 $37^{\prime \prime} \mathrm{E}$ $20^{\circ} 51^{\prime} 49^{\prime \prime}, 828 \mathrm{~m}$ a.s.1.) and Ohrid Lake (1 indiv.; $\mathrm{N} 40^{\circ} 59^{\prime} 01^{\prime \prime} \mathrm{E}$ $20^{\circ} 38^{\prime} 23^{\prime \prime}, 690 \mathrm{~m}$ a.s.1.). All crayfish individuals were preserved in $96 \%$ ethanol and deposited in the invertebrate collection of National Museum, Prague, Czech Republic (accession numbers P6E 4180-4184). They were morphologically identified as $A$. astacus (Füreder and Machino, 2002). The DNA barcoding of the mitochondrial gene for the cytochrome $c$ oxidase subunit I (COI; as in Mrugała et al., 2015) confirmed morphological identification and revealed the presence of three haplotypes (fragments' length 635 base pairs (bp), GenBank accession numbers: KY682289-91). There are no shared haplotypes between the localities and the haplotypes differ by up to three mutations. The mitochondrial network for COI was constructed by TCS 1.21 (Clement et al., 2000) using statistic parsimony. The analyses revealed that the Albanian A. astacus haplotypes are distinct from the ones published by Schrimpf et al. (2011, 2014; Fig. 1) for the great part of native distribution of this species.

In addition to our observations in Ohrid Lake and upper Devolli River, $A$. astacus population is apparently present in the Albanian part of Prespa Lake, from where 54 individuals were recently purchased from a local fisherman (Đuretanović et al., 2017). Moreover, the early studies repeatedly reported its presence in transboundary waterbodies in neighbouring countries and from several drainages in a close vicinity to Albania. It was mentioned as Potamobius fluviatilis balcanicus in Karaman (1929); Astacus colchicus balcanicus in Karaman
(1962); Astacus astacus balcanicus in Karaman (1963) and Albrecht (1982) in Ohrid Lake and rivers of the Vardar system in the Former Yugoslav Republic of Macedonia (FYROM) and in the Sitnica River (Danube drainage) in Kosovo. The presence of $A$. astacus (as Potamobius astacus) in Ohrid Lake was also mentioned by Stanković (1960) and reported from the Zeta River (Ohrid-Drin-Skadar basin) in Montenegro (Simić et al., 2008). Finally, it is also widespread in the north-western and central regions of Greece (including the Kalamas River near the southern Albanian border; Koutrakis et al., 2007).

Austropotamobius torrentium occurs throughout the Balkans (Kouba et al., 2014) and its presence was recently confirmed in Albania (Subchev, 2011). A voucher specimen sampled in the northern part of the country in 2003 (River Fani i Madh, Mat River basin, N 42 $04^{\prime} 59^{\prime \prime}$ E $20^{\circ} 03^{\prime} 36^{\prime \prime}, 615 \mathrm{~m}$ a.s.1.) is deposited in the collection of the Natural History Museum in Budapest, Hungary (Subchev, 2011). The studies of Karaman (1929), Karaman (1962, 1963) and Albrecht (1982) indicated also that A. torrentium (as Potamobius torrentium macedonicus - Karaman (1929), Austropotamobius torrentium natio macedonicus - Karaman (1962), Austropotamobius torrentium - Albrecht (1982)) is present in FYROM, including Ohrid Lake as well as the Drim and Vardar river systems. Moreover, its occurrence was also suggested for Skadar Lake and its tributaries in Albania and Montenegro (Karaman, 1962). Presence in the Montenegrin part of the Skadar Lake basin was confirmed from the Rijeka Crnojevića (rather small direct inflow of Skadar Lake; Trontelj et al., 2005; Petrović et al., 2013). Furthermore, this crayfish species was recorded in the Morača River (main inflow of Skadar Lake) in Montenegro (Simić et al., 2008). It is also widely present in central and southern part of Serbia (including Morava, Timok and Drina rivers; Simić et al., 2008), as well as in northern Greece, where its western distribution extends to the area around the city of Kastoria, close to Albanian border (Koutrakis et al., 2007).

Austropotamobius pallipes occurs on the Dalmatian coast with its southernmost distribution limit in the Zeta River in Montenegro, a part of the Ohrid-Drin-Skadar system (Machino and Ďuriš, 2004; Rajković et al., 2012; Kouba et al., 2014). In contrast, $A$. leptodactylus inhabits only the north-eastern part of the Balkan Peninsula (Kouba et al., 2014). It was suggested that it might be recorded in Albania with more intensive sampling (Holdich, 2002), nevertheless, its presence has not been confirmed yet. The distribution of $A$. leptodactylus in neighbouring countries is limited to the central part of Serbia (Danube basin including Sava, Morava and Timok rivers; Karaman, 1929; Simić et al., 2008), as well as to the Evros River drainage in eastern Greece (Koutrakis et al., 2007). In addition, two non-native crayfish species of North American origin are present in the Balkans: the spiny-cheek crayfish, Orconectes limosus (reported from the Serbian stretch of the Danube; Simić et al., 2008) and the signal crayfish, Pacifastacus leniusculus occurring at several localities in north-eastern Croatia as well as in northern Greece in Lake Agra in the Aliakmon River basin (Koutrakis et al., 2007; Kouba et al., 2014).

Our observations confirm A. astacus presence in Albania and demonstrate its occurrence also in the Albanian part of Ohrid Lake. Furthermore, although A. torrentium was not recorded during our surveys, it is present in the northern part of Albania and may be also expected to inhabit other freshwaters, especially close to Macedonian, Montenegrin and Greek 


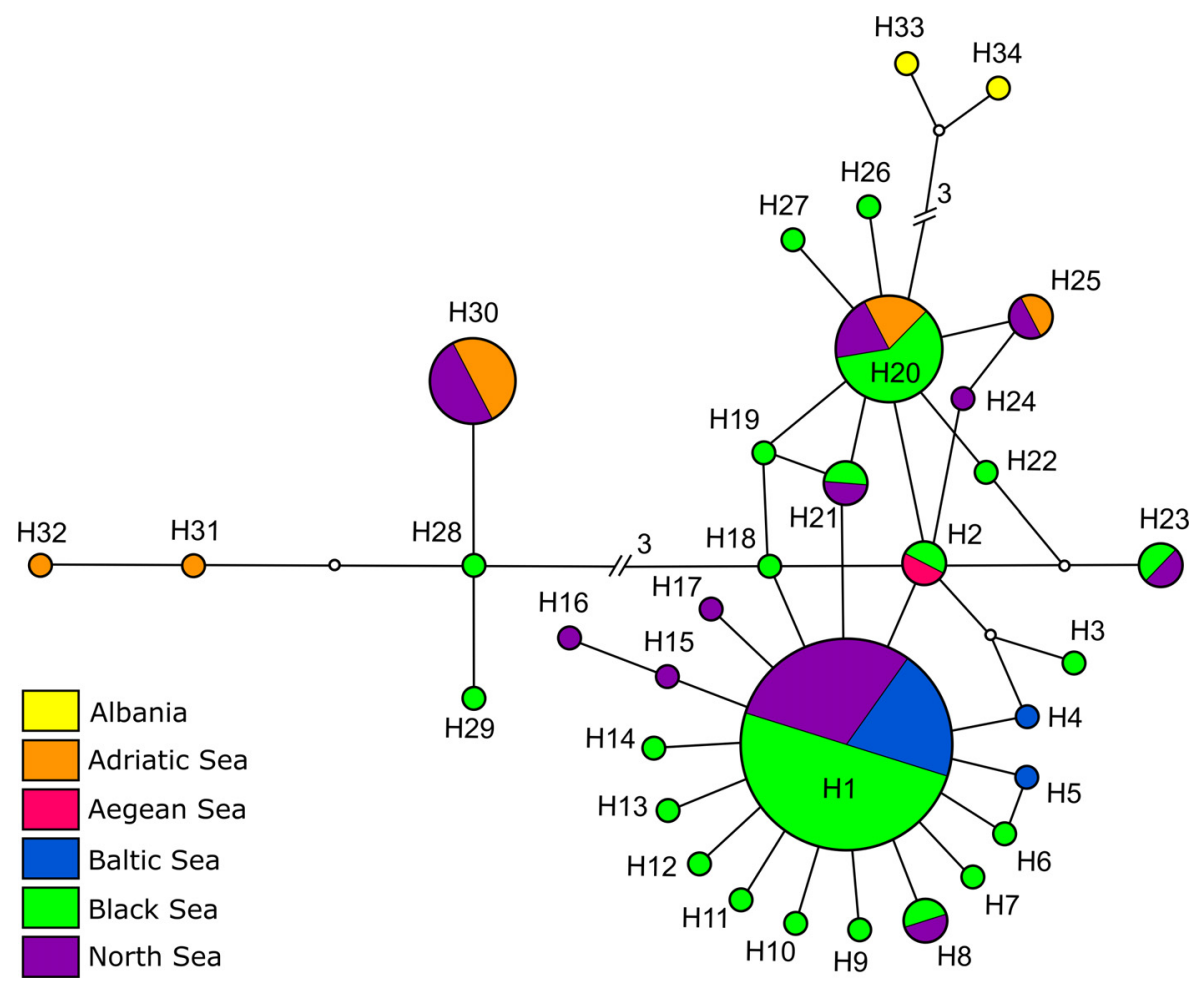

Fig. 1. The network of COI haplotypes that includes A. astacus haplotypes from Albanian localities (Ohrid Lake and Devolli River, both Adriatic Sea basin; obtained in the present study) and from five sea basins: Adriatic Sea (Croatia, Montenegro), Aegean Sea (Kosovo), Black Sea (Austria, Bulgaria, Croatia, Germany, Hungary, Romania), Baltic Sea (Germany, Poland), North Sea (Belgium, Czech Republic, Germany; published in Schrimpf et al., 2011, 2014). The size of the circles is proportional to the frequency of the represented haplotypes at the country level in all five sea basins. Only two haplotypes from Albania are presented (from Ohrid Lake and Devolli River); due to the shorter length of the published $A$. astacus sequences (350 base pairs [bp]) the diversity of haplotypes from the Devolli River was lost (based on full length $635 \mathrm{bp}$, three haplotypes were found). The white dots indicate the median vectors. The number of base pair changes is given (no number indicates a change of $1 \mathrm{bp}$ ). The details on the haplotypes published in Schrimpf et al. $(2011,2014)$ are provided as a Supplementary Material.

borders. As recent reports of the IUCN (International Union for Conservation of Nature) highlight declines of both crayfish species in Ohrid Lake and its tributaries most likely caused by water pollution (Edsman et al., 2010; Füreder et al., 2010), it should not be neglected that it may be the case also for the other Albanian waterbodies. The natural expansion of $A$. pallipes from the Zeta River in Montenegro (Rajković et al., 2012) to Albania, as well as of the two North American crayfish species from neighbouring countries seems unlikely. However, the distribution ranges of crayfish species in Europe are nowadays strongly shaped by deliberate or accidental anthropogenic introductions, e.g., through the use of crayfish as fishing bait, their illegal stocking or releases of unwanted ornamental pets (Holdich et al., 2009; Peay 2009). Therefore, only long-term and intensive sampling may provide the data on the exact distribution of both already recorded native European crayfish species in Albanian freshwaters, as well as may reveal the presence of any other non-native crayfish species.

\section{Supplementary Material}

Table S1. The codes and GenBank accession numbers of COI haplotypes published in Schrimpf et al. (2011, 2014) used for network analyses in the present study.
The Supplementary Material is available at https://www.kmaejournal.org/10.1051/kmae/2017024/olm.

Acknowledgements. This research was supported by the Ministry of Culture of the Czech Republic (DKRVO 2017/ 15, National Museum, 00023272) and by the institutional resources of the Ministry of Education, Youth, and Sports of the Czech Republic.

\section{References}

Albrecht H. 1982. Das System der europäischen Flußkrebse (Decapoda, Astacidae): Vorschlang und Begründung. Mitt Hamb Zool Mus Inst 79: 187-210.

Bănărescu PM. 2004. Distribution pattern of the aquatic fauna of the Balkan Peninsula. In: Griffiths HI, Kryštufek B, Reed JM, eds. Balkan biodiversity: pattern and process in the European Hotspot. Dordrecht: Kluwer Academic Publishers, pp. 203-219.

Clement M, Posada D, Crandall K. 2000. TCS: a computer program to estimate gene genealogies. Mol Ecol 9: 1657-1660.

Đuretanović S, Jaklič M, Milošković A, et al. 2017. Morphometric variations among Astacus astacus populations from different regions of the Balkan Peninsula. Zoomorphology 136: 19-27.

Edsman L, Füreder L, Gherardi F, Souty-Grosset C. 2010. Astacus astacus. The IUCN Red List of Threatened Species 2010: e.T2191A9338388. 
Füreder L, Machino Y. 2002. A revised determination key of freshwater crayfish in Europe. Berichte des Naturwissenschaftlich Medizinischen Vereins in Innsbruck 89: 169-178.

Füreder L, Gherardi F, Souty-Grosset C. 2010. Austropotamobius torrentium. The IUCN Red List of Threatened Species 2010: e.T2431A9439449.

Grandjean F, Frelon-Raimond M, Souty-Grosset C. 2002. Compilation of molecular data for the phylogeny of the genus Austropotamobius: one species or several? Bull Fr Pêche Piscic 367: 671-680.

Hewitt GM. 1999. Post-glacial re-colonization of European biota. Biol J Linnean Soc 68: 87-112.

Holdich D. 2002. Distribution of crayfish in Europe and some adjoining countries. Bull Fr Pêche Piscic 367: 611-650.

Holdich DM, Reynolds JD, Souty-Grosset C, Sibley PJ. 2009. A review of the ever increasing threat to European crayfish from nonindigenous crayfish species. Knowl Manag Aquat Ecosyst 394-395: 11 .

Jelić M, Klobučar GI, Grandjean F, et al. 2016. Insights into the molecular phylogeny and historical biogeography of the whiteclawed crayfish (Decapoda, Astacidae). Mol Phylogenet Evol 103: $26-40$.

Karaman S. 1929. Die Potamobiiden Jugoslaviens. Glasnik Zemaljskog Muzeja u Bosni i Hercegovini 41: 147-150.

Karaman M. 1962. Ein Beitrag zur Systematik der Astacidae (Decapoda). Crustaceana 3: 173-191.

Karaman M. 1963. Studie der Astacidae (Crustacea, Decapoda). II. Teil. Hydrobiologia 22: 111-132.

Klobučar GIV, Podnar M, Jelić M, et al. 2013. Role of the Dinaric Karst (western Balkans) in shaping the phylogeographic structure of the threatened crayfish Austropotamobius torrentium. Freshw Biol 58: 1089-1105.

Kouba A, Petrusek A, Kozák P. 2014. Continental-wide distribution of crayfish species in Europe: update and maps. Knowl Manag Aquat Ecosyst 413: 5.

Koutrakis E, Perdikaris C, Machino Y, Savvidis G, Margaris N. 2007. Distribution, recent mortalities and conservation measures of crayfish in Hellenic freshwaters. Bull Fr Pêche Piscic 385: 25-44.

Machino Y, Duriš Z. 2004. New data and verification on the geographical distribution of the crayfish genus Austropotamobius from Bosna-i-Hercegovina, Montenegro and Bulgaria. Crayfish News 26: 8-10.

Maguire I, Jelić M, Klobučar G. 2011. Update on the distribution of freshwater crayfish in Croatia. Knowl Manag Aquat Ecosyst 401: 31.

Maguire I, Podnar M, Schrimpf A, Schulz H. 2014. Two distinct evolutionary lineages of the Astacus leptodactylus species complex (Decapoda: Astacidae) inferred by phylogenetic analyses. Invertebr Syst 28: $117-123$.

Mrugała A, Kozubíková-Balcarová E, Chucholl C, et al. 2015. Trade of ornamental crayfish in Europe as a possible introduction pathway for important crustacean diseases: crayfish plague and white spot syndrome. Biol Invas 17: 1313-1326.

Peay S. 2009. Invasive non-indigenous crayfish species in Europe: recommendations on managing them. Knowl Manag Aquat Ecosyst 394-395: 03.

Petrović A, Rajković M, Simić S, Maguire I, Simić V. 2013. Importance of genetic characteristics in the conservation and management of crayfish in Serbia and Montenegro. Bulg J Agric Sci 19: 1093-1104.

Rajković M, Petrović A, Maguire I, Simić V, Simić S, Paunović M. 2012. Discovery of a new population of the species complex of the white-clawed crayfish, Austropotamobius pallipes/italicus (Decapoda, Astacidae) in Montenegro, range extension, endangerment and conservation. Crustaceana 85: 333-347.

Reynolds J, Souty-Grosset C, Richardson A. 2013. Ecological roles of crayfish in freshwater and terrestrial habitats. Freshw Crayfish 19: 197-218.

Richman NI, Böhm M, Adams SB, et al. 2015. Multiple drivers of decline in the global status of freshwater crayfish (Decapoda: Astacidea). Phil Trans $R$ Soc B 370: 20140060.

Schrimpf A, Schulz HK, Theissinger K, Pârvulescu L, Schulz R. 2011. The first large-scale genetic analysis of the vulnerable noble crayfish Astacus astacus reveals low haplotype diversity in central European populations. Knowl Manag Aquat Ecosyst 401: 35.

Schrimpf A, Theissinger K, Dahlem J, et al. 2014. Phylogeography of noble crayfish (Astacus astacus) reveals multiple refugia. Freshw Biol 59: 761-776.

Simić V, Petrović A, Rajković M, Paunović M. 2008. Crayfish of Serbia and Montenegro - the population status and the level of endangerment. Crustaceana 81: 1153-1176.

Sket B, Paragamian K, Trontelj P. 2004. A census of the obligate subterranean fauna of the Balkan Peninsula. In: Griffiths HI, Kryštufek B, Reed JM, eds. Balkan biodiversity: pattern and process in the European hotspot. Dordrecht: Kluwer Academic Publishers, pp. 309-322.

Stanković S. 1960. The Balkan Lake Ohrid and its living world. In: Junk W, ed. Monographiae Biologicae, Vol. IX. Den Haag: Uitgeverij, p. 197.

Subchev M. 2011. First record of Branchiobdella Odier, 1823 (Annelida: Clitellata) in Albania and an overview of the geographic distribution of Branchiobdella hexodonta Gruber, 1882 in Europe. Acta Zool Bulg 63: 109-112.

Trontelj P, Machino Y, Sket B. 2005. Phylogenetic and phylogeographic relationships in the crayfish genus Austropotamobius inferred from mitochondrial COI gene sequences. Mol Phylogenet Evol 34: 212-226.

Trožić-Borovac S. 2011. Freshwater crayfish in Bosnia and Herzegovina: the first report on their distribution. Knowl Manag Aquat Ecosyst 401: 26.

Cite this article as: Mrugała A, Šanda R, Shumka S, Vukić J. 2017. Filling the blank spot: first report on the freshwater crayfish distribution in Albania. Knowl. Manag. Aquat. Ecosyst., 418, 34. 